\title{
The Turning Point in International Development Cooperation of South Korea
}

\author{
Hyomin Jung \\ The center for African Area Studies, Kyoto University, 46 Yosida Simoadachi, Sakyo, Kyoto, Japan
}

\begin{abstract}
Clarifying how South Korean aid had been changed during the procedures to join Organisation for Economic Cooperation and Development, Development Assistance Committee (DAC), and the background why South Korea made a decision to become a DAC member are the main purposes of this study. Prior researches have identified a few reasons that clarifying emerging donor's DAC entering mainly focused on external factors. This study describes South Korea's decision to join DAC had been decided through domestic debates, unlike previous studies. The policy documents and qualitative interviews used to analyze the changes of aid and background in South Korea, especially during the 2000s. In 2005, the South Korean government announced a plan for aid policy reforms by 2010. The establishment of the Committee for International Development Cooperation for comprehensive aid policy-making expansion of aid volume, and the increase in grant ratio were the major changes in this process. The members involved in Official Development Assistance policy reforms were not only officials but professionals who pursued a career in civil society as well. The Indian Ocean earthquake and tsunami in 2004 worked as one of the catastrophic events that pushed Korea to shift to real policy reform, but more than that, there was a social consensus on South Korea's obligation to become an international donor.
\end{abstract}

Keywords: ODA, Korea, DAC, Emerging donor

DOI: $10.7176 / \mathrm{JLPG} / 98-30$

Publication date:June 30th 2020

\section{Introduction}

In 2010, Korea joined the Development Assistance Committee (DAC) of the Organization for Economic Cooperation and Development (OECD DAC), which is a group of donor countries. The Korean government had decided to become a DAC member in the mid-2000s. The transition was a turning point for Korea in getting the identity of an aid-giver country. This paper examines the changes in the Korean aid policy in the 2000s. In addition, the factors that made Korea join the OECD's DAC will be discussed while focusing on the debates in Korea over the country's domestic policy.

\section{Debates on the emerging donors joining the DAC}

The DAC has been playing a role as a donor council in developed donor countries since the 1960s (Riddel, 2008). On the other hand, China and India, as well as many developing countries, have maintained South-South Cooperation (SSC) with other developing countries in various fields (Manning 2006; Mawdsley, 2012; Walz \& Ramachandran, 2011). These aid-like activities, which are not defined as aid by the DAC, have been around for many years (Walz \& Ramachandran, 2011). In the 2000s, SSC among developing countries continued to increase with the rise in the economic growth of emerging countries (Mawdsley, 2012). Especially China's role in SSC has begun to grow rapidly. The volume of China's SSC has been particularly remarkable enough to impress not only the other DAC donor countries but also recipient countries (Naim, 2007). This phenomenon was new to the DAC member countries, who had provided overwhelming quantitative aid to recipient countries until the mid-2000s. Thus, cooperative debates and systems on ODA and SSC as development cooperation have been essential for developing countries' growth (Benn \& Luijkx, 2017).

Under these circumstances, the majority of northern developed countries joined the DAC until the 1980s, except for few developed countries that had small populations and geographical areas. In the 2010s, a few emerging donor countries from OECD started to join the DAC as official members. South Korea joined the DAC in 2010, Poland, Slovenia, Slovakia, Czech Republic, and Iceland in 2013, and Hungary in 2016. Except for South Korea and Iceland, the other joining countries were located in Central or Eastern Europe. These countries experienced a transition from socialist to capitalist economy after the Cold War. External pressure duties of the EU had been a factor to join DAC (Lightfoot \& Szent-Iványi, 2015). ${ }^{1}$ Central and Eastern European countries received support from Western countries not only for their transition from socialism to a capitalism but also in setting up organizations and the methods of aid (Lightfoot \& Szent-Iványi, 2015).

Unlike Central and Eastern European countries who wanted to join the EU, South Korea did not have much peer pressure to become a DAC member, On the other hand, one of the motives for Korea to be a DAC member was debt repayment as South Korea was given aid from the international society (Kim, 2011). Korea had grown from a developing country to emerge as one of the OECD countries with aid (Chun et al., 2010; The Export-Import bank of Korea, 2010). Though there are indications in previous studies that DAC membership is a symbol of a 
country's entry into a group of developed nations, which is related to the issue of diplomatic power as a middle power (Kondoh, 2015), it has not yet been analyzed as to how and why the discussions in Korea began and pushed it to join the DAC. Korea is the first emerging donor county outside Europe to join the DAC. The Central and Eastern European countries were peer-pressured owing to their duty for being an EU country. As South Korea is not an EU member, joining the DAC membership began with domestic debates rather than external pressure. In this regard, this study uses the policy documents of the Korean government to focus on the changes in the country's aid policy and the discussions in Korea regarding these alterations, especially during the 2000s.

\section{Background: Korean aid before 2000s}

In the latter half of the $1980 \mathrm{~s}$, South Korea was under pressure from the international community to share the burden as an emerging nation (Kondoh, 2013). Simultaneously, Korea was motivated to provide aid with the aim of securing resources and promoting Korean companies' export chances (Kim, 2016). The Economic Development Cooperation Fund (EDCF) was established in 1987 as an organization that provides loans, and four years later, in 1991, the Korea International Cooperation Agency (KOICA) was founded as an organization providing grants and technical assistance. Both institutions learned from Japan about setting up aid agencies (Kondoh, 2013). However, since the 1960s, Japan has formed various levels of consultative bodies on aid policy, including the mechanisms to hold ministers' meetings led by Japan's Prime Minister, who is the chief executive of the government and has been discussing aid policy (Arase, 1995). Despite this background, during this period, Korea did not have a comprehensive government policy coordination mechanism that could discuss both grants and loans together.

"South Korea will expand the scale of official development assistance for developing countries to a level commensurate with its economic capacity," President Kim Young Sam said in his speech at the UN Summit Meeting in 1995, the time when Korea had decided to become a member of the OECD. ${ }^{2}$ However, the economic crisis in 1997 strengthened the idea that aid should be linked to "national interests" within bureaucratic organizations (Lee, 2003). From this perspective, Korea's aid until around 2002 was still close to that of emerging donors who were aiming for reciprocity.

\section{Changes in Korean aid from 2005 to 2010}

The DAC has standards for countries that wanted to join the committee. According to the DAC, the admission process begins with submitting a letter from the country aspiring to become a member of the DAC Secretariat (OECD, 2004). Subsequently, the Secretariat reviews the application and conducts visits to the candidate countries' development co-operation headquarters. The important standards offered by the DAC through this process include the following: i) the existence of appropriate strategies, policies, and institutional frameworks, ii) an accepted measure of the effort (e.g., ODA/GNI ratio over $0.20 \%$ or ODA volume above $\$ 100$ million), and iii) the existence of a system of performance monitoring and evaluation (OECD, 2004). Furthermore, the candidate country needs to pledge to fulfill the obligations of the DAC membership, such as implementing the recommendations from the DAC, providing annual ODA statistics, and participating in all meetings of the DAC (OECD, 2004).

From 2005 to 2010, the Korean government had changed the aid policy based on the policy document "Comprehensive Measures for Improving Foreign Aid." This document intended to organize the country's aid system, including the establishment of a coordinating organization for aid, the enactment of a legal base of ODA, the expansion of the scale of aid, elevating the quality of aid, setting a monitoring and evaluation system, and enlarging partnerships with the nongovernmental sector (Office for Government Policy Coordination, 2005a). In addition, in the document, Korean government indicated that joining the DAC until 2010 will be considered depending on the financial condition of the government (Office for Government Policy Coordination, 2005a). Korea already had enough volume of aid from the DAC standards of admission, and in 2005, it needed strategies, policies, institutional frameworks, and evaluation system. From this perspective, it was the most important turning point for Korea to join the DAC, as these comprehensive measures of the Korean government fulfilled the core conditions of the DAC admission.

4.1 Coordinating organization: Establishment of the Committee for International Development Cooperation (2006) Based on the policy reform decision stated in Comprehensive Measures for Improving Foreign Aid in 2005, the Committee for International Development Cooperation (CIDC) was set up in 2006 to make decisions on Korean aid through comprehensive discussions. This committee was established by a Presidential Decree in 2006, and as the Framework Act on International Development Cooperation (Framework Act) was enacted in 2010, it has a basis for the existence of the CIDC. There is no fundamental difference in the contents of the CIDC between the 2006 Presidential Decree and the 2010 law. ${ }^{3}$ The members of the CIDC, which is chaired by the Prime Minister, are the heads of relevant government ministries, the president of the Export-Import Bank of Korea, which operates the EDCF, the president of KOICA, and civilian experts (Framework Act on International Development Cooperation, 2013). The CIDC decides the operation plan of international development cooperation, the annual comprehensive plan for each sector, evaluation of international development cooperation, and the matters related 
to international development cooperation that need to be coordinated by the entire government.

\subsection{Enactment of the Basic Law on International Development Cooperation: Framework Act on International Development Cooperation (2010)}

As a result of the document Comprehensive Measures for Improving Foreign Aid, the Framework Act on International Development Cooperation (Framework Act) was enacted in 2010 and amended 2013. First, Article 1 of the Framework Act describes the purpose of the law as follows: "The purpose of this Act is to enhance the appropriateness of policies for international development cooperation and the effectiveness of implementation thereof, and effectively achieve the policy objectives of international development cooperation by providing for basic matters concerning international development cooperation, thus contributing to the co-prosperity of humanity and to world peace" (Framework Act on International Development Cooperation, 2013). ${ }^{4}$ Specifically, the basic spirit and goals are set out in Article 3. Article 3 states, "The basic ideas of international development cooperation is to reduce poverty, improve the human rights of women, children, people with disabilities, and youth, achieve gender equality, realize sustainable development and humanitarianism in developing countries, promote economic cooperation relationship with partner countries and pursue peace and prosperity in the international community" (Framework Act on International Development Cooperation, 2013). ${ }^{5}$ In fact, there has been some debate within the national assembly, regarding the purposes of aid, such as the phrase "promote economic cooperation relationship with partner countries," as a means of pursuing the interests of the Korean side (Proceedings of the 18th National Assembly, 2009). Nevertheless, it basically reflected the DAC's perception of aid in the Framework Act on International Development Cooperation. ${ }^{6}$

\subsection{The expansion of the scale of aid}

Table 1. The volume of Korean ODA (2002-2010)

\begin{tabular}{|l|c|c|c|c|c|c|c|c|c|}
\hline & 2002 & 2003 & 2004 & 2005 & 2006 & 2007 & 2008 & 2009 & 2010 \\
\hline Total ODA & 278.78 & 365.91 & 423.32 & 752.32 & 455.25 & 696.11 & 802.34 & 816.04 & $1,173.79$ \\
\hline ODA/ GNI \% & 0.05 & 0.06 & 0.06 & 0.1 & 0.05 & 0.07 & 0.09 & 0.1 & 0.12 \\
\hline
\end{tabular}

Disbursement, Unit: US dollars, Millions, \%, (Source) OECD Stat.

Further, significant changes have been made between 2005 and 2010 in the volume and form of aid. Korea set targets for the period from 2005 to 2009 and steadily expanded the scale of aid. In 2005, when the document Comprehensive Measures for Improving Foreign Aid was created, the average DAC member country's ODA to Gross National Income (GNI) ratio was $0.25 \%$. This is why the aim had been set to $0.25 \%$ (Office for Government Policy Coordination, 2005a, p. 16). In 2009, the ratio of GNI per ODA reached $0.1 \%$, as it was targeted in 2005. In 2005 alone, the amount of aid increased exceptionally, but this was a sudden increase in support for reconstruction during the Iraq War. From the contents of Table 1, the ratio of ODA to GNI and total aid, on average, increased at a steady pace until 2010.

\subsection{Elevating the quality of aid}

There have been changes not only in the scale of the aid but also in the quality of the aid. The Comprehensive Measures for Improving Foreign Aid document states that South Korea needs to be aware of the tendencies in the international community to implement aid reform: focusing on poverty reduction, including the Millennium Development Goals (MDGs) (Office for Government Policy Coordination, 2005a, p. 1). For this reason, although no concrete figures have been given in 2005 , the government stated in the document that the proportion of grant aid will be expanded.

There was a year in which the amount of the grant exceeded that of loan aid, but from 2005 to 2010, the amount of grant aid has consistently exceeded the loan aid. This has been partly affected by the support to Iraq and Afghanistan because Korea is an ally of the United States. In particular, Korea's assistance to Iraq from 2003 to 2007 accounted for a large percentage of bilateral aid. Iraq was the biggest recipient country in 2005; ODA to Iraq accounted for $32.28 \%$ of total bilateral assistance. ${ }^{7}$ Further, ODA to Afghanistan accounted for $10.4 \%$ in $2010 .^{8}$ This support was primarily provided through grants. In the result, as Table 2 indicates, the share of the grants greatly increased.

Table 2. Ratio of loan and grant (2002-2010)

\begin{tabular}{|l|c|c|c|c|c|c|c|c|c|}
\hline & 2002 & 2003 & 2004 & 2005 & 2006 & 2007 & 2008 & 2009 & 2010 \\
\hline \multirow{4}{*}{ Grant } & 66.7 & 145.46 & 212.09 & 318.00 & 258.95 & 358.33 & 368.67 & 366.97 & 573.89 \\
& $(32.26)$ & $(59.33)$ & $(64.12)$ & $(68.64)$ & $(68.86)$ & $(73.05)$ & $(68.37)$ & $(63.15)$ & $(63.72)$ \\
\hline & 140.06 & 99.71 & 118.68 & 145.3 & 117.11 & 132.19 & 170.55 & 214.13 & 326.7 \\
Loan & $(67.74)$ & $(40.67)$ & $(35.88)$ & $(31.36)$ & $(31.14)$ & $(26.95)$ & $(31.63)$ & $(36.85)$ & $(36.28)$ \\
\hline & 206.76 & 245.17 & 330.76 & 463.30 & 376.06 & 490.52 & 539.22 & 581.10 & 900.63 \\
Bilateral ODA & $(100)$ & $(100)$ & $(100)$ & $(100)$ & $(100)$ & $(100)$ & $(100)$ & $(100)$ & $(100)$ \\
\hline
\end{tabular}

Disbursement, Unit: US dollar, Millions, \%, (Source) OECD Stat. 
The discussions on the ratio of the grants and loans have continued since 2005. In the DAC countries, the grant aid was $86.2 \%$ from 2005 to 2006 (OECD, 2008b, p. 184). South Korea increased its grant aid but did not reach the average level of the DAC, which was approximately more than $80 \%$.

\subsection{Changes in the evaluation system}

KOICA established an evaluation office in 1998 and set the internal evaluation standards in 2006 (OECD, 2008a). The EDCF also has an evaluation system; however, there was no internal evaluation team, and this evaluation unit was temporarily set up for evaluation of each project (OECD, 2008a). In December 2009, the Korean government established an evaluation subcommittee as a subordinate body of the CIDC (OECD, 2012). This evaluation subcommittee's primary role is to review and approve the annual evaluation plan for each aid implementation (OECD, 2012). Though the evaluation system has been created, in 2009, there were some limitations such as the joint evaluation system cannot be considered fully functional, as it has not evaluated all projects (OECD, 2012). 4.6 Enlarging partnerships with the nongovernmental sector

The number of Korean NGOs increased since the 1990s, and development cooperation NGOs continued to increase in the 2000s. According to the data of the CSO Handbook for International Development Cooperation 2013, which had been published by the Korea NGO Council for Overseas Development Cooperation (KCOC), in the 1980s, there were four Korean nongovernmental organizations, which had started the development cooperation projects for developing countries. In the 1990s the number of organizations which had started overseas development cooperation projects in Korea increased to 25 and almost doubled to 54 in the 2000s (Korea NGO Council for Overseas Development Cooperation, 2013, p. 15).

In addition, KOICA's cooperation with NGOs increased in the mid to late $2000 \mathrm{~s}$. This was a form of subsidy from the ODA budget to projects implemented by NGOs in developing countries. The support for NGOs had continued to increase from 2005, except for 2009. The ODA budget, which had supported the NGO activities in developing countries, had increased from \$ 2.76 million in 2005 to \$ 6.31 million in 2008 and reached $\$ 7.87$ million in $2010 .^{9}$

\section{Domestic debates related to becoming a donor country}

\subsection{Public awareness of aid}

Around the beginning of the 2000 s, the public perception of aid began to change. The earthquake in Turkey, on August 17, 1999, attracted considerable public attention in Korea. Compared to the South Korean government's \$70,000 donation to Turkey in response to the disaster, the donations from the general public amounted to approximately \$ 1 million (Hong, 1999; Kwon, 1999). The newspapers and television in Korea raised the attention that Korea needed to give back, as Turkey was one of the countries that had participated in the Korean War as part of the UN force. The criticism of the government's response to such international disasters also began to be reported at this time (Kwon, 1999).

In December 2004, the Great Sumatra Earthquake and the Indian Ocean tsunami disaster caused great destruction. According to government figures, the amount raised from NGOs, companies, and general donations was approximately $\$ 48.98$ million. This amount was almost equal to $\$ 50$ million that Korean government had actually supported for the emergency relief for 2004 Tsunami (Ministry of Foreign Affairs and Trade, 2005, p. 35). According to a public opinion poll conducted by the Office for Government Policy Coordination in Korea in August 2005, 62.3\% agreed in favor of providing aid to developing countries (Office for Government Policy Coordination, 2005 b, p. 1). Since the early 2000s, there was public opinion that South Korea should be more responsible for what is happening in developing countries as a member of international society. 


\subsection{Debates on ODA policy}

Table 3. Comparison of critical contents in Proposal for Improvements of Official Development Assistance and Comprehensive Measures for Improving Foreign Aid

\begin{tabular}{|c|c|c|}
\hline & $\begin{array}{l}\text { Proposal for Improvements of } \\
\text { Official Development } \\
\text { Assistance（December 2004 ) }\end{array}$ & $\begin{array}{c}\text { Comprehensive Measures for Improving Foreign } \\
\text { Aid (November 2005) }\end{array}$ \\
\hline ODA/GNI \% & Increase to $0.1 \%$ until 2009 & Tentative agreement increases to $0.1 \%$ until 2009 \\
\hline Quality of ODA & $\begin{array}{l}\text { Priority partner countries } \\
\text { Country partnership strategy }\end{array}$ & $\begin{array}{l}\text { Increase the proportion of grant } \\
\text { Priority partner countries } \\
\text { Country partnership strategy }\end{array}$ \\
\hline $\begin{array}{l}\text { Decision-making } \\
\text { system }\end{array}$ & $\begin{array}{l}\text { Promotion of working-level } \\
\text { coordination committee }\end{array}$ & Establishment of Foreign Aid Policy Committee \\
\hline Legal basis & Law for grant aid & Foreign aid law \\
\hline $\begin{array}{l}\text { Partnership with } \\
\text { nongovernmental } \\
\text { sector }\end{array}$ & $\begin{array}{l}\text { Strengthening public promotions } \\
\text { regarding ODA } \\
\text { Expansion in NGO support }\end{array}$ & $\begin{array}{l}\text { Participation in NGOs and business circles on the } \\
\text { Foreign Aid Policy Committee } \\
\text { Expansion in NGO support }\end{array}$ \\
\hline $\begin{array}{l}\text { Monitoring and } \\
\text { evaluation }\end{array}$ & $\begin{array}{l}\text { Reinforcement of monitoring and } \\
\text { evaluation }\end{array}$ & $\begin{array}{l}\text { Reinforcement of monitoring and evaluation, } \\
\text { implementation of external evaluation systems }\end{array}$ \\
\hline Joining DAC & Aims to join DAC in 2006 & Considers to join DAC around 2010 \\
\hline
\end{tabular}

(Sources) Conducted based on the contents of Korean Presidential Commission on Sustainable Development (2004), Office for Government Policy Coordination (2005a)

The government document Comprehensive Measures for Improving Foreign Aid had a major impact on Korean aid reforms in the late 2000s. This document included the majority of the challenges encountered by the government in 2010. Therefore, it is important why the Korean government decided to make such a change. The first debate within the government related to the need for Korea to have a better aid mechanism as a donor began in 2002 at the Korean Presidential Commission on Sustainable Development (PCSD). Especially, the development of the document Comprehensive Measures for Improving Foreign Aid in 2005 was very similar to the document "Proposal for Improvements of Official Development Assistance," which had been written by the PCSD at the end of 2004 (Compare the contents of the two documents in Table 3). The relationship between the two documents reveals how the debates processed within the government.

5.2.1 Opinion leaders' awareness of ODA: The Proposal for Improvements of Official Development Assistance by external experts of PCSD

The Korean PCSD was not one of the ministries in the government. The PCSD was established in September 2000 as the Presidential Advisory Committee. Its establishment had been influenced by international society. After the Rio Declaration on environment and development in 1992, the United Nations recommended the member countries to set up a mechanism for implementation and evaluation of Agenda 21, based on an action plan. At the time of the Rio Declaration, South Korea's self-awareness was still of a developing country. Therefore, despite the UN recommendations, there was no immediate establishment of the recommended mechanism for implementation of Agenda 21 in South Korea.

In 1999, seven years after the Rio Declaration, various actors, including Korean civil society, the media, and academia urged the government to establish a state organization for sustainable development. President Kim Daejung agreed to establish the Presidential Advisory Committee on Sustainable Development, which was launched in September 2000. ${ }^{10}$ The foundation of the PCSD was based on the Presidential Decree. The Roh Moo-hyun administration, which succeeded the Kim Dae-jung administration, had decided to continue with the PCSD activities. Irrespective of the change in the administration, the PCSD continued its activities as one of the National Agenda Committee for fulfilling the President's manifesto. As the Sustainable Commission was basically established as a mechanism for implementation and evaluation of sustainable development, the Johannesburg Declaration on Sustainable Development, which was a Rio+10 meeting, in 2002, became an agenda to consider the future plan for Rio+10 goals. The Johannesburg Declaration stated, "We urge developed countries that have not done so to make concrete efforts toward the internationally agreed levels of Official Development Assistance" (United Nations, 2002). In response, the PCSD set up an ODA subcommittee to start discussions on aid. ${ }^{11}$ The members of ODA subcommittee included government officials, but the majority comprised experts from various fields such as nongovernmental organizations and private sectors. These core members, who were not from the government, played a role in drafting aid reforms, coordinating various opinions, and finalizing the proposal for the President.

In order to reflect on the Johannesburg Declaration, it was necessary to understand the current state of Korean aid. The PCSD formulated approaches for effecting a change in ODA. In the Johannesburg Declaration, specific features of ODA were not mentioned, but a reference was made to "the internationally agreed levels of Official 
Development Assistance" (United Nations, 2002). The ODA subcommittee referred to MDGs and the DAC guidelines, which were considered to reflect on the "consensus of the world" required by the Johannesburg Declaration, and with that, the ODA subcommittee measured how Korean ODA was far away from the global consensus (Presidential Commission on Sustainable Development, 2004).

A more challenging task was the formation of loan-aid and grant-aid as an integrated policy. Until the early2000s, ODA had been viewed as economic and diplomatic tools by the Ministry of Finance and Economy (MOFE) and Ministry of Foreign Affairs and Trade (MOFAT) in Korea. ${ }^{12}$ The ODA subcommittee discussed to set basic directions for ODA as a whole. Further, discussions were held with the officials of government organizations, such as the MOFE and the MOFAT, to come up with a comprehensive policy proposal, including loans and grants (Presidential Commission on Sustainable Development, 2004). The members of the ODA subcommittee referred to the DAC guidelines in making a draft for ODA reforms (Presidential Commission on Sustainable Development, 2004). The agreed perception among the members of the subcommittee was that the purpose of the aid should be the DAC's definition of ODA, which defines "the promotion of the economic development and welfare of developing countries as its main objective" (Interviews, 2015).

Despite the subcommittee's ideal perception of aid, it was not easy to coordinate the opinions of the ministries that actually had the ODA budget (Interviews, 2015). Though both the MOFE and the MOFAT agreed on the need to increase the budget as a donor country, deciding on the ratio of loan and grant was difficult as this was directly related to the issue of raise in the budgets of related ministries. Furthermore, it was related to the decision on which ministry could take the initiative regarding the complete aid policy.

The ODA subcommittee's report, which summarized the opinions of the actors in government ministries after discussions, was a proposal achieved through a realistic coordination. Nevertheless, the ODA subcommittee presented a proposal for aid reforms with a greater emphasis on global consensus: enlarging aid volume to the average level of the DAC countries, expanding grant aid and untied aid, setting a law for aid, and joining the DAC. The ODA subcommittee's report was the first turning point that the debates had started in converting South Korea's SSC to aid at the government level.

5.2.2 Government's policy process: Formulation of the ODA Improvement Task Force Team's Comprehensive Measures for Improving Foreign Aid

The PCSD was one of the presidential advisory committees. From the nature of the government committee, even if the PCSD made an advisory proposal for the President, it was the government's decision, whether to reflect the result to the proposal. A proposal by the ODA subcommittee of the Sustainability Commission was in the same situation. As aid policy was not a major policy in Korea, the priority of the policy was low as well. There was a possibility that this proposal might not be taken up by the government. The ODA subcommittee submitted its final proposal titled the Proposal for Improvements of Official Development Assistance to the President on December 20,2004

Shortly after this proposal was submitted to the President, the Indian Ocean tsunami occurred on December 26,2004 . The disaster was so huge that it had a global impact, with more than 227,000 casualties (Telford et al., 2006, p. 16). The scale of the damage was huge, requiring a large amount of emergency assistance and restoration funds (Athukorala \& Resosudarmo, 2005, p. 2). The donor countries started to support the damaged areas, even competing with each other in terms of the amount of aid. Each country aimed to show its presence in Asia along with humanitarian objectives (Zhang, 2006).

The Korean government was not an exception. Initially, the amount of Korea's assistance was $\$ 5$ million in December 2004, but it expanded to $\$ 50$ million in January 2005 (Ministry of Foreign Affairs and Trade, 2005). This expansion was due to the decision by Prime Minister Lee Hae-chan. Prime Minister Lee later said in an interview to a newspaper: "At that time, Japan and China brought a huge amount of \$ 300 million $\$ 500$ million. I thought it was embarrassing as Korea at the initial amount" (Park et al., 2016). Subsequently, the South Korean government had taken proactive measures to support those affected in the Indian Ocean tsunami, emphasizing its obligations to the international community (Ministry of Foreign Affairs and Trade, 2005).

With this regard, on April 30, 2005, the State Affairs Committee on Resource Allocation decided to expand the size of ODA to $0.1 \%$ of GNI by 2009 as a condition for improvement of aid efficiency. For this, a Task Force Team for Improvement of Official Development Assistance was set up in the Office for Government Policy Coordination under the Prime Minister (Office for Government Policy Coordination, 2005a). The Task Force Team for ODA of the Office for Government Policy Coordination comprised the government officials, the officials of aid agencies, and external experts. The team exchanged opinions with stakeholders and formed policy proposals, holding informal workshops with government officials, aid agencies, and civil society groups (Interview, 2016). In order to confirm public opinion, Office for Government Policy Coordination conducted a public opinion poll in August 2005 (Office for Government Policy Coordination, 2005b).

The contents included data on public awareness about aid, and whether Korea needs to provide aid to developing countries as a donor, and if so, for what reason. In the survey, $37.1 \%$ said they knew that South Korea provided aid as a donor, and $62.3 \%$ agreed that Korea should provide assistance to developing countries as a donor 
(Office for Government Policy Coordination, 2005b, p. 1). The primary reasons for assistance by Korea, in public opinion, were "for peaceful co-existence of humankind" $(28.9 \%)$ and "because Korea has also benefited in the past" (27.7\%) (Office for Government Policy Coordination, 2005b, p. 2). According to the survey, the public opinion was relatively positive for aid. On November 16, 2005, the document Comprehensive Measures for Improving Foreign Aid was announced. The content of this plan was the basis of aid policy reforms to be implemented by 2010 .

The aid policy reform of Korea had been debated internally within the government due to the need to fulfill the responsibilities as a member of international society after overcoming the domestic economic crisis. Southeast Asian countries, which had been active partners of Korea in aspects of economic exchanges, such as trade, investment, and tourism, were severely affected in 2004 by the Indian Ocean tsunami.

The primary contents of the subcommittee's Proposal for Improvements of Official Development Assistance were finalized just before the Indian Ocean tsunami incident. Consequently, the Proposal for Improvements of Official Development Assistance has come to be linked to actual policies in many aspects. Though there were some limitations, the policy document Comprehensive Measures for Improving Foreign Aid, announced in 2005, was the first step toward making Korea a donor country.

\section{Processes of joining the DAC}

Since the announcement of Comprehensive Measures for Improving Foreign Assistance document in 2005, the Korean government has been steadily proceeding with the specific preparations to become a DAC member by 2010, which was mentioned in the document. The "Vision 2030," which is a long-term national vision announced in 2006, currently includes the contents of ODA that expand the scale of the aid to the DAC average level and prepares an evaluation system (Government-Private Joint Working Group, 2006). According to the "OECD Development Assistance Committee (DAC) Membership Roadmap (draft)" document, the preparations by Korea to join the DAC were also made within the government in 2007. The ministries related to ODA jointly checked the conditions to gain the DAC membership status. In this document, the requirements for joining the DAC and schedule were discussed (Committee for International Development Cooperation, 2007).

The DAC conducted a special review of South Korea in 2008 and mentioned the following points regarding DAC membership: South Korea's international cooperation as a whole needs a law for development assistance, a comprehensive ODA plan, and a medium-term strategy. In addition, it is necessary to raise the volume of ODA (OECD, 2008a). The DAC also highlighted the improvement points such as the need for evaluation criteria based on international standards, the emphases aid based on the Paris Declaration on aid effectiveness, and the need to expand humanitarian aid (OECD, 2008a).

After the DAC was reviewed by 2009, South Korea officially became a DAC member in 2010, and the CIDC issued the "International Development Cooperation Advancement Plan" in 2010. It stated that the DAC recommendations will be implemented (Committee for International Development Cooperation, 2010, p. 12). In 2012, the first peer review was conducted in South Korea, and the DAC presented an evaluation of Korean ODA compared to 2008 and referred to 2012 challenges (OECD, 2012, p. 12). First, Korea has created laws and strategies for development cooperation, which has made it possible to manage the budget for development assistance funds more clearly than before, but it requires an integrated framework of policy processes (OECD, 2012, p. 12). Regarding the scale and the content of aid, it is evaluated that the budget has been steadily expanded from 2006 to 2011 , and it is necessary to expand it to the $0.25 \%$ level by 2015 (OECD, 2012, p. 15). In addition, Korea set up an evaluation committee under the CIDC to conduct the integrated evaluation, but the evaluation system and influence were still insufficient, and it was necessary to strengthen it (OECD, 2012, pp. 18-19). The DAC also pointed out that additional effort would be needed in terms of effectiveness and humanitarian assistance (OECD, 2012).

\section{Conclusion}

Since the mid-2000s, South Korea has set up a system as a member of an international donor country. The primary changes during this period include an enlargement of the volume of aid, setting the coordinating organization, and enactment of the basic law for aid. In addition, the number of actors involved in the aid policy has increased and experts from the nongovernmental sector have participated in the aid decision-making process. Since then, the public documents on aid have been released to public, and the decision-making process has become open since the inclusion of the CIDC by external experts. At this turning point, The Comprehensive Measures for Improving Foreign Aid document, which had been made and announced by a Task Force Team for Improvement of Official Development Assistance, has played a major role. The "Proposal for Improvements of Official Development Assistance," which was proposed by the ODA subcommittee on sustainability in 2004, has been a draft of the document known as Comprehensive Measures for Improving Foreign Aid. The majority of nongovernmental experts, who led this proposal in 2004, were conscious that "it is necessary to be aware of the international consensuses on aid, such as Rio+10 declaration and the DAC guidelines to fulfill our obligations as a donor." The 
2004 Indian Ocean tsunami was one of the accidental occasions that led Korea to become a DAC donor country.

However, from a broader perspective, this implicated that the perceptions, regarding the undertaking of obligations required by the international community from a developed nation, existed in Korea. This awareness allowed the President and Prime Minister of Korea to accept the PCSD's proposal decision at the State Council to increase the aid volume as a condition to make aid policy reform. In the $2010 \mathrm{~s}$, as emerging donors emerged, the DAC's influence relatively had decreased than before, but for Korea, the DAC membership was still a symbol of being a developed country. This paper examines the changes and backgrounds in Korea's international development cooperation focused on the 2000s. The modalities of South Korea's aid have been shifted since then, affected by not only internal factors but external factors as well, as South Korea became one of the members of DAC. Further studies are needed on how internal and external factors worked in South Korea's development cooperation after DAC entering.

\section{References}

Arase, D. (1995). Buying power: The political economy of Japan's foreign aid. Colorado: Lynne Rienner Publishers.

Athukorala, P. C., \& Resosudarmo, B. P. (2005). The Indian Ocean tsunami: Economic impact, disaster management, and lessons. Asian Economic Papers, 4(1), 1-39.

Benn, J., \& Luijkx, W. (2017). Emerging providers' international co-operation for development. OECD Working Papers. Paris: OECD.

Chun, H. M., Munyi, E. N., \& Lee, H. (2010). South Korea as an emerging donor: Challenges and changes on its entering OECD/DAC. Journal of International Development, 22(6), 788-802.

Committee for International Development Cooperation. (2007). OECD Development Assistance Committee (DAC) Membership Roadmap (draft), Committee for International Development Cooperation.

Committee for International Development Cooperation. (2010). International Development Cooperation Advancement Plan, Committee for International Development Cooperation.

The Export-Import bank of Korea. (2010). EDCF Annual report 2010. Seoul: The Export-Import bank of Korea.

Framework Act on International Development Cooperation. (2013). [Online] Available: http://www.law.go.kr/lsInfoP.do?lsiSeq=160744\&chrClsCd=010203\&urlMode=engLsInfoR\&viewCls=eng LsInfoR\#0000(December 23, 2019).

Government-Private Joint Working Group. (2006). Vision 2030. [Online] Available: [https://change.parti.xyz/file_source/63/download] (December 10, 2017).

Hong, S. (1999). Discussions on campaign for Turkey 'To be born as a global citizen.' Dongailbo, September 29, 1999. [Online] Available: http://www.donga.com/news/article/all/19990928/7472766/1 (March 11, 2020).

Interview. (2016). Anonymous interview on the ODA Task Force team.

Interviews. (2015). Anonymous interviews on PCSD.

Kim, S. (2011). Bridging troubled worlds? An analysis of the ethical case for South Korean aid. Journal of International Development, 23(6), 802-822.

Kim, S. (2016). Tracing the roots and domestic sources of Korea's ODA : Aid as a cold war statecraft for a middle income country. Journal of International Cooperation Studies, 24(1), 87-102.

Kondoh, H. (2013). Korea's pathway from recipient to donor: How does Japan matter? In The Rise of Asian Donors, Routledge. 141-162.

Kondoh, H. (2015). Convergence of aid models in emerging donors? Learning processes, norms and identities, and recipient (JICA RI working paper, No. 106). JICA Research Institute.

Korea NGO Council for Overseas Development Cooperation. (2013). International Development Cooperation CSO Handbook. Seoul: KCOC.

Kwon, J. (1999). Fundraising for an earthquake in Turkey, Dongailbo, October 2. [Online] Available: http://goo.gl/YJw8Wv (March 11, 2020).

Lee, T. (2003). An anthropological study of the Korean foreign aid policy: Making advanced country and development discourse. Cross-cultural Studies, 9(1), 139-174.

Lightfoot, S., \& Szent-Iványi, B. Z. (2015). New Europe's new development aid. Abingdon Oxon: Routledge.

Manning, R. (2006). Will emerging donors change the face of international cooperation? Development Policy Review, 24(4), 371-385.

Mawdsley, E. (2012). From recipients to donors: Emerging powers and the changing development landscape. New York: Zed Books.

Ministry of Foreign Affairs and Trade. (2005). Our South Asia Earthquake Tsunami Restoration Support Activities. Seoul: Ministry of Foreign Affairs and Trade.

Naim, Moises. (2007). Rogue aid. Foreign policy, 159, 95-96.

OECD. (2004). Aide mémoire on the admission of new DAC members. Paris: OECD.

OECD. (2008a). OECD development co-operation special reviews, Republic of Korea. Paris: OECD. 
OECD. (2008b). OECD Development Co-operation Report 2007. Paris: OECD.

OECD. (2012). Korea development assistance committee (DAC) Peer review 2012. Paris: OECD.

OECD. (2019). Official Development Assistance (ODA). Paris: OECD.

Office for Government Policy Coordination. (2005a). Comprehensive Measures for Improving Foreign Aid, Office for Government Policy Coordination.

Office for Government Policy Coordination. (2005b). Public opinion survey on Official Development Assistance, Office for Government Policy Coordination.

Park, S. et al. (2016). Special talk: Munjong Inn meets former Prime Minister, Lee Hae-chan. Monthly Jungang, August 17. [Online] Available: https://jmagazine.joins.com/monthly/view/312834 (April 10, 2020).

Presidential Commission on Sustainable Development (PCSD). (2004). A Proposal for improvements of Official Development Assistance. Sustainability Committee, 2004-24. Presidential Commission on Sustainable Development [Online] Available: pcsd.pa.go.kr/board/download.php?db=bbs41\&uid= 26] (December 10, 2017).

President Kim Young Sam's speech in United Nations Social Development Summit (March 11, 1995). Presidential Memorial [Online] Available: http://www.pa.go.kr/research/contents/speech/inde x04_result.jsp (April 4, 2017).

Proceedings of the 18th National Assembly. (2009). 284th 9th Foreign Affairs and Trade, Unification Committee, November 25, National Assembly.

Riddell, R. C. (2008). Does foreign aid really work?. New York: Oxford University Press.

Telford, J., Cosgrave, J., \& Houghton, R. (2006). Joint evaluation of the international response to the Indian Ocean tsunami. Synthesis Report. London: Tsunami Evaluation Coalition.

United Nations. (2002). Johannesburg declaration on sustainable development. United Nations. [Online] Available: http://www.un-documents.net/jburgdec.htm (December 8, 2017).

Walz, J., \& Ramachandran, V. (2011). Brave new world: A literature review of emerging donors and the changing nature of foreign assistance (Center for Global Development working paper 273). Washington, DC: Center for Global Development.

Zhang, J. (2006). Public diplomacy as symbolic interactions: A case study of Asian tsunami relief campaigns. Public Relations Review, 32(1), 26-32.

\section{Databases}

OECD Statistics: http://stats.oecd.org/

KOICA Statistics http://stat.koica.go.kr/

\footnotetext{
Notes

${ }^{1}$ Iceland, which has been an OECD member since the formation of the organization, was already a developed country in the 1960s. Therefore, Iceland is excluded from the discussion on emerging donors in this paper. Iceland is a small country with a population of 1 million or less under other conditions. Luxembourg, a small country with similar conditions as Iceland, became a DAC member in 1991. Luxembourg joined the DAC relatively later compared to EU countries with similar economic level (most OECD/EU Concurrent Member States joined the DAC between the 1960s and 1980s)

${ }^{2}$ President Kim Young Sam's UN speech at the United Nations Social Development Summit (March 11, 1995).

${ }^{3}$ The law amended July 25, 2011 and acted July 16, 2013.

${ }^{4}$ The law amended July 25, 2011 and acted July 16, 2013. The purpose of the law had not been changed.

5"Improve the human rights of women, children, people with disabilities, " was added from the 2010 law to 2013 amend.

${ }^{6}$ One of the DAC's definitions of ODA "promotes and specifically targets the economic development and welfare of developing countries" as its main objective (OECD, 2019).

${ }^{7}$ OECD Statistics: OECD http://stats.oecd.org/ (accessed July 4, 2016).

${ }^{8}$ OECD Statistics: OECD http://stats.oecd.org/ (accessed July 4, 2016).

${ }^{9}$ KOICA Statistics: http://stat.koica.go.kr (accessed August 1, 2019).

${ }^{10}$ Korean Presidential Commission on Sustainable Development. [Online] Available: http://pcsd.pa.go.kr/ about/about02.html(Accessed August 8, 2019).

${ }^{11}$ The official name of ODA subcommittee was the "Foreign Aid Sub-Committee in Social Education Committee" in the second term (October 2002-December 2003) and of Sustainability Committee was the "External Assistance Sub-Committee within the Social Subcommittee" in the third term (December 2003-December 2004). Since both subcommittees are in charge of reviewing the same matters, and both had been referred to as "ODA subcommittees" in the PCSD in abbreviated form, in this study, both are referred to as "ODA subcommittees."

${ }^{12}$ The ministries' names were changed from the Ministry of Finance and Economy (MOFE) to Ministry of
} 
Economy and Finance (MOEF) and the Ministry of Foreign Affairs and Trade (MOFAT) to Ministry of Foreign Affairs (MOFA) in 2008 as a result of Governmental Reorganization. 